\title{
HEPATIC METABOLISM OF CHOLESTEROL IN EXPERIMENTAL NEPHROSIS IN RATS *
}

\author{
BY RAY H. ROSENMAN, WILLIAM BREALL, SANFORD O. BYERS AND \\ DAVID D. RABIN \\ (From the Harold Brunn Institute, Mount Zion Hospital and Medical Center. \\ San Francisco, Cal.)
}

(Submitted for publication March 20, 1959; accepted April 30, 1959)

The nephrotic state induced in rats by injection of rabbit antirat kidney serum (AKS) closely resembles that occurring clinically (1). Our previous studies indicated that the AKS-induced hypercholesteremia in such rats cannot be ascribed to any increase of cholesterol synthesis (2) or intestinal absorption (3), or to any decrease of its intestinal excretion (4). In view of the important role of the liver $(5,6)$ in the disposition of the plasma cholesterol, we also believed it important to study any possible role of some AKSinduced abnormality of the liver in the genesis of nephrotic hypercholesteremia.

\section{METHODS AND RESULTS}

Young adult, male rats (Long-Evans) were used. In preliminary tests the pooled rabbit antirat kidney serum (AKS) (1) used herein was shown to induce significant hypercholesteremia within 24 hours after its intravenous administration. Plasma was variously analyzed

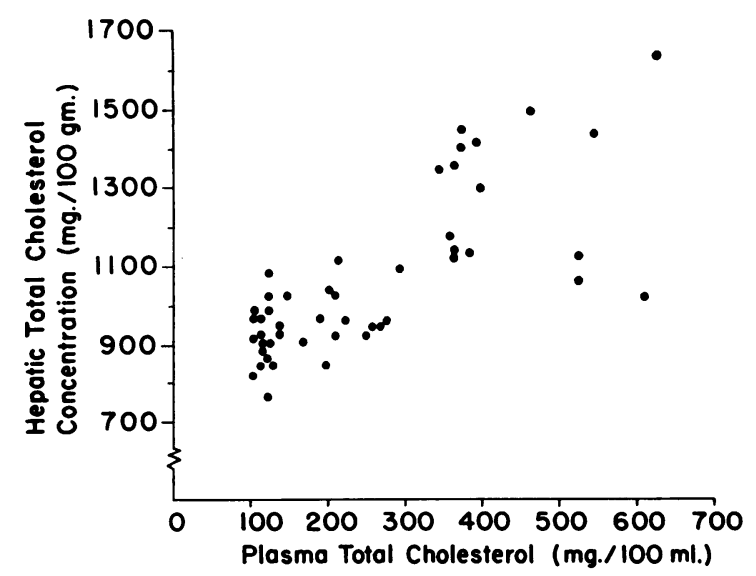

Fig. 1. Relationship of Plasma and Liver CholesTEROL IN NEPHROTIC RATS

* This work was supported by grants from the American Heart Association, National Institutes of Health (A-1213), and the Northern California Chapter of the National Kidney Disease Foundation, Inc. for total cholesterol (7), phospholipids (8) and total lipids (9), liver for total cholesterol (10), and bile for bile acid (cholate) (11) concentrations.

A. Effect of nephrosis on hepatic content and hepaticplasma exchange of cholesterol. Methods: The hepatic cholesterol content was determined in 55 rats at various intervals up to 10 days following injection of $1.0 \mathrm{ml}$. of AKS. A diet low in fat and sterols was fed during this time. Plasma total cholesterol, and also total lipids in certain instances, were determined at the time of sacrifice. Normal values were established in 20 control rats.

For purposes of comparison, plasma and liver cholesterol also were determined in: a) six rats six hours after intravenous injection of $25 \mathrm{mg}$. of cholesterol, contained in hypercholesteremic rat serum prepared by the hypercholatemic method $(12), b)$ in five other rats four days after daily stomach feedings of $100 \mathrm{mg}$. cholesterol in $3 \mathrm{ml}$. of olive oil, and $c$ ) in five additional rats 24 hours after intravenous injection of $100 \mathrm{mg}$. of Triton ${ }^{\circledR}$ WR-1339. ${ }^{1}$

\section{Results}

Hypercholesteremia was induced by AKS 24 hours after its injection (see Table I, Group 2). However, despite the presence of persistent hypercholesteremia, no significant rise of liver cholesterol concentrations occurred until 72 or more hours after AKS injection, and there was no direct relationship between the plasma and liver cholesterol concentrations of these rats (see Figure 1). Although a rise of liver cholesterol occurred after 72 hours following AKS injection (see Table I, Groups 5 to 8), probably indicating the egress from plasma of some of its excess cholesterol content at this time, the plasma and liver cholesterol concentrations remained only poorly correlated (see Figure 1), suggesting that the late rise of liver cholesterol following AKS injection is a function more of time than of the plasma cholesterol concentration.

\footnotetext{
${ }^{1}$ Rohm and Haas Co. brand name for $p$-iso-octyl polyoxyethylenephenol polymer.
} 
TABLE I

Hepatic content of cholesterol in nephrotic rats

\begin{tabular}{|c|c|c|c|c|c|c|c|}
\hline \multirow[b]{4}{*}{ Group } & \multirow{4}{*}{$\begin{array}{l}\text { No. of hours } \\
\text { after AKS } \\
\text { injection }\end{array}$} & \multirow{4}{*}{$\begin{array}{c}\text { No. of } \\
\text { rats }\end{array}$} & \multicolumn{5}{|c|}{ Average Concentration } \\
\hline & & & \multicolumn{2}{|c|}{ Plasma } & \multicolumn{3}{|c|}{ Liver } \\
\hline & & & \multirow{2}{*}{$\begin{array}{c}\begin{array}{c}\text { Total } \\
\text { cholesterol }\end{array}\end{array}$} & \multirow[b]{2}{*}{ Total lipids } & \multirow{2}{*}{$\underset{\text { weight }}{\text { Dry }}$} & \multicolumn{2}{|c|}{ Total cholesterol } \\
\hline & & & & & & Concentration & Content \\
\hline & & & \multicolumn{2}{|c|}{$\mathrm{mg} . / 100 \mathrm{ml}}$. & $\mathrm{Gm}$. & $m g_{.} / 100 \mathrm{Gm}$. & mg./organ \\
\hline 1 & 0 & 20 & $\begin{array}{c}55 \\
(41-68) \dagger\end{array}$ & $\begin{array}{c}208 \\
(165-233)\end{array}$ & $\begin{array}{l}2.31 \pm 0.14^{*} \\
(1.96-3.16)\end{array}$ & $\begin{array}{l}893 \pm 29.1 \\
(715-1,080)\end{array}$ & $\begin{array}{c}20.63 \pm 0.80 \\
(17.1-24.2)\end{array}$ \\
\hline 2 & 24 & 15 & $\begin{array}{c}142 \\
(102-209)\end{array}$ & & $\begin{array}{l}2.03 \pm 0.08 \\
(1.54-2.51)\end{array}$ & $\begin{array}{l}926 \pm 15.1 \\
(812-1,030)\end{array}$ & $\begin{array}{c}18.80 \pm 0.96 \\
(16.3-24.8)\end{array}$ \\
\hline 3 & 30 & 9 & $\begin{array}{c}116 \\
(101-124)\end{array}$ & & $\begin{array}{l}2.15 \pm 0.08 \\
(1.75-2.18)\end{array}$ & $\begin{array}{l}980 \pm 28.3 \\
(767-1,100)\end{array}$ & $\begin{array}{c}21.07 \pm 0.44 \\
(16.7-24.9)\end{array}$ \\
\hline 4 & 48 & 5 & $\begin{array}{c}198 \\
(124-250)\end{array}$ & & $\begin{array}{c}2.21 \pm 0.27 \\
(1.81-2.52)\end{array}$ & $\begin{array}{l}984 \pm 28.4 \\
(933-1,088)\end{array}$ & $\begin{array}{r}21.75 \pm 2.2 \\
(18.3-24.2)\end{array}$ \\
\hline 5 & 72 & 8 & $\begin{array}{c}203 \\
(148-267)\end{array}$ & $\begin{array}{c}1,392 \\
(992-1,792)\end{array}$ & $\begin{array}{c}2.25 \pm 0.13 \\
(1.81-2.72)\end{array}$ & $\begin{array}{r}1,021 \pm 20.7 \\
(948-1,120)\end{array}$ & $\begin{array}{r}22.97 \pm 1.5 \\
(18.1-30.5)\end{array}$ \\
\hline 6 & 96 & 10 & $\begin{array}{c}444 \\
(365-624)\end{array}$ & $\begin{array}{c}2,135 \\
(1,048-4,055)\end{array}$ & $\begin{array}{c}2.09 \pm 0.07 \\
(1.70-2.40)\end{array}$ & $\begin{array}{l}1,251 \pm 49.2 \\
(1,060-1,640)\end{array}$ & $\begin{array}{r}26.14 \pm 1.2 \\
(21.2-31.7)\end{array}$ \\
\hline 7 & 7 days & 5 & $\begin{array}{c}452 \\
(357-544)\end{array}$ & & $\begin{array}{c}2.20 \pm 0.18 \\
(1.75-2.79)\end{array}$ & $\begin{array}{l}1,342 \pm 67.1 \\
(1,134-1,500)\end{array}$ & $\begin{array}{r}29.52 \pm 3.2 \\
(20.0-40.6)\end{array}$ \\
\hline 8 & 10 days & 3 & $\begin{array}{c}370 \\
(364-376)\end{array}$ & $\cdot$ & $\begin{array}{c}2.50 \\
(2.23-2.68)\end{array}$ & $\begin{array}{c}1,329 \\
(1,138-1,420)\end{array}$ & $\begin{array}{c}33.23 \\
(29.4-31.6)\end{array}$ \\
\hline
\end{tabular}

* Standard error of mean.

$\dagger$ Range of values.

A similar dissociation of plasma and liver cholesterol concentrations was observed (see Table II) in another hypercholesteremic state characterized by the intravascular retention of incoming lipid (13). Thus, a normal content of liver cholesterol was found in rats recently injected with Triton ${ }^{\circledR}(13)$, despite the presence of severe hypercholesteremia (Table II, Group 5). In contrast in the rats injected with (Group 3), or fed excess, cholesterol (Group 4), marked rise of liver cholesterol occurred, the rapidly falling or normal plasma cholesterol levels in such rats indicating the rapid clearance from the plasma and hepatic uptake of such administered excess cholesterol (5).

B. Effect of nephrosis on the hepatic conversion and elimination of cholesterol. Although the previous results indicated that nephrotic hypercholesteremia did not stem from any AKS-induced accumulation of liver cholesterol, it was also believed important to study the effect of nephrosis upon the rate of hepatic elimination of cholesterol, and upon the liver's ability to convert cholesterol

TABLE II

Hepatic cholesterol content in various hypercholesteremic states

\begin{tabular}{|c|c|c|c|c|c|c|}
\hline \multirow[b]{3}{*}{ Group } & \multirow[b]{3}{*}{ Type of rat } & \multirow[b]{3}{*}{$\begin{array}{l}\text { No. of } \\
\text { rats }\end{array}$} & \multicolumn{4}{|c|}{ Average total cholesterol concentration } \\
\hline & & & \multirow[b]{2}{*}{ Plasma } & \multicolumn{3}{|c|}{ Liver } \\
\hline & & & & $\begin{array}{c}\text { Dry } \\
\text { weight }\end{array}$ & Concentration & Content \\
\hline $\begin{array}{l}1 \\
2 \\
3 \\
4 \\
5\end{array}$ & $\begin{array}{l}\text { Control } \\
48 \text { hrs. after injection of AKS } \\
6 \text { hrs. after injection of hypercholesteremic rat serum } \\
4 \text { days after daily gavage of cholesterol and olive oil } \\
24 \text { hrs. after injection of Triton }\end{array}$ & $\begin{array}{r}20 \\
5 \\
6 \\
5 \\
5\end{array}$ & $\begin{array}{c}\text { mg./100 ml. } \\
55 \\
198 \\
154 \dagger \\
60 \\
440\end{array}$ & $\begin{array}{l}G m . \\
2.31 \\
2.21 \\
2.20 \\
2.61 \\
2.46\end{array}$ & $\begin{array}{c}m g . / 100 \mathrm{Gm} . \\
893 \pm 29.1 * \\
984 \pm 28.4 \\
1,285 \pm 35.2 \\
1,794 \pm 150.1 \\
913 \pm 24.0\end{array}$ & $\begin{array}{c}\text { mg./organ } \\
20.6 \\
21.8 \\
28.3 \\
46.8 \\
22.5\end{array}$ \\
\hline
\end{tabular}

* Standard error of mean.

† Plasma cholesterol averaged $248 \mathrm{mg}$. per $100 \mathrm{ml}$. immediately after the injection of hypercholesteremic rat serum. 
to cholate, the principal end-product of hepatic metabolism of cholesterol (5).

Methods: 1. Hepatic elimination of exogenously derived cholesterol. The effect of nephrosis on hepatic elimination of cholesterol was studied in rats in which an excess hepatic cholesterol content was induced in two different ways. The first series of 39 rats was fed a diet containing excess cholesterol ( 3 per cent) and olive oil (3 per cent) for 14 days. Nine rats were sacrificed at this time and the remaining rats transferred to stock ration. Then, 15 of the 30 remaining rats were injected with $1.0 \mathrm{ml}$. of AKS, the remainder serving as paired controls. Groups of five AKS-injected and five controls were then sacrificed three, seven and 11 days after being transferred to stock ration. In each instance plasma total lipids and total cholesterol and liver total cholesterol were determined. For comparative purpose, similar analyses were done in five normal rats and in five rats injected seven days previously with AKS but fed stock ration.

2. Hepatic elimination of endogenously derived cholesterol. Each of a second series of 70 rats was injected with $3.2 \mathrm{ml}$. of pooled hypercholesteremic rat serum (HCRS) containing $25 \mathrm{mg}$. of cholesterol and $60 \mathrm{mg}$. of phospholipids. Such serum, prepared by feeding cholic acid to otherwise starved rats with ligated bile ducts (12), was found to have only a negligible content of triglycerides. A concomitant injection of $1.0 \mathrm{ml}$. of AKS was given to 18 of the rats, and groups of six of these latter rats were sacrificed immediately and six and 24 hours later for determination of plasma and liver cholesterol. Five additional rats were sacrificed for similar analyses 48 hours after injection of the HCRS, but were injected with AKS 24 hours after the HCRS administration. The remaining 47 rats served as controls, also being sacrificed at various intervals following injection of HCRS.

3. Hepatic conversion of cholesterol to cholate. The effect of nephrosis upon the hepatic conversion of cholesterol to cholate was studied in a third series of rats. A group of eight rats was fed a diet containing added cholesterol (2 per cent) and olive oil (3 per cent) for 10 days. Three of the rats were then injected with AKS, the remaining five rats serving as their controls. The bile ducts were cannulated (14) and bile collected during the ensuing 24 hours. A second group of 12 rats was injected with $25 \mathrm{mg}$. of cholesterol contained in $3.2 \mathrm{ml}$. of the pooled hypercholesteremic rat serum (12), four of the rats having been injected six hours previously with AKS. Bile was collected during a 12 hour interval from these rats. For further control purposes, bile also was collected for 24 hours from a group of eight normal rats

TABLE III

Effect of nephrosis on rate of hepatic elimination of pre-fed dietary cholesterol

\begin{tabular}{|c|c|c|c|c|c|c|c|c|}
\hline \multirow[b]{4}{*}{ Group } & \multirow{4}{*}{$\begin{array}{l}\text { No. of days } \\
\text { after AKS } \\
\text { injection }\end{array}$} & \multirow{4}{*}{$\underset{\text { given* }}{\text { AKS }}$} & \multirow{4}{*}{$\begin{array}{c}\text { No. of } \\
\text { rats }\end{array}$} & \multicolumn{5}{|c|}{ Average concentration } \\
\hline & & & & & & \multicolumn{3}{|c|}{ Liver } \\
\hline & & & & \multicolumn{2}{|c|}{ Plasma } & \multirow[b]{2}{*}{ Dry weight } & \multicolumn{2}{|c|}{ Total cholesterol } \\
\hline & & & & Total lipids & Total cholesterol & & Concentration & Content \\
\hline \multicolumn{9}{|c|}{ A. Rats pre-fed fat-cholesterol diet for 14 days } \\
\hline 1 & 0 & - & 9 & $\begin{array}{c}576 \\
(405-785) \dagger\end{array}$ & $\begin{array}{c}260 \\
(117-363)\end{array}$ & $\begin{array}{c}4.25 \\
(3.74-4.73)\end{array}$ & $\begin{array}{c}17,171 \\
(14,120-19,410)\end{array}$ & $\begin{array}{c}730 \\
(564-865)\end{array}$ \\
\hline $2(\mathrm{a})$ & 3 & + & 5 & $\begin{array}{c}2,894 \\
(2,110-4,160)\end{array}$ & $\begin{array}{c}1,226 \\
(1,030-1,597)\end{array}$ & $\begin{array}{c}3.78 \\
(3.65-3.91)\end{array}$ & $\begin{array}{c}14,470 \\
(13,100-16,250)\end{array}$ & $\begin{array}{c}547 \\
(477-636)\end{array}$ \\
\hline (b) & & - & 5 & $\begin{array}{c}233 \\
(118-262)\end{array}$ & $\begin{array}{c}69 \\
(58-95)\end{array}$ & $\begin{array}{c}4.20 \\
(3.60-5.38)\end{array}$ & $\begin{array}{c}13,783 \\
(11,940-15,700)\end{array}$ & $\begin{array}{c}579 \\
(493-643)\end{array}$ \\
\hline $3(a)$ & 7 & + & 5 & $\begin{array}{c}4,232 \\
(2,807-6,110)\end{array}$ & $\begin{array}{c}1,857 \\
(1,149-2,494)\end{array}$ & $\begin{array}{c}3.00 \\
(2.28-3.63)\end{array}$ & $\begin{array}{c}14,138 \\
(10,730-17,460)\end{array}$ & $\begin{array}{c}424 \\
(240-588)\end{array}$ \\
\hline (b) & & - & 5 & $\begin{array}{c}193 \\
(134-223)\end{array}$ & $\begin{array}{c}72 \\
(60-92)\end{array}$ & $\begin{array}{c}3.16 \\
(2.87-3.46)\end{array}$ & $\begin{array}{c}12,227 \\
(10,670-13,840)\end{array}$ & $\begin{array}{c}386 \\
(346-422)\end{array}$ \\
\hline $4(a)$ & 11 & + & 5 & & $\begin{array}{c}171 \\
(100-264)\end{array}$ & $\begin{array}{c}3.12 \\
(2.67-3.88)\end{array}$ & $\begin{array}{c}3,682 \\
(1,965-5,300)\end{array}$ & $\begin{array}{c}115 \\
(55-206)\end{array}$ \\
\hline (b) & & - & 5 & & $\begin{array}{c}52 \\
(47-56)\end{array}$ & $\begin{array}{l}3.19 \\
(2.74-3.56)\end{array}$ & $\begin{array}{c}4,619 \\
(2,750-6,900)\end{array}$ & $\begin{array}{c}147 \\
(91-398)\end{array}$ \\
\hline \multicolumn{9}{|c|}{ B. Control rats pre-fed stock ration for 14 days } \\
\hline 5 & 0 & - & 5 & $\begin{array}{c}187 \\
(140-225)\end{array}$ & $\begin{array}{c}57 \\
(42-68)\end{array}$ & $\begin{array}{c}2.85 \\
(2.51-3.41)\end{array}$ & $\begin{array}{c}815 \\
(730-1,000)\end{array}$ & $\begin{array}{c}23.2 \\
(18.7-25.7)\end{array}$ \\
\hline 6 & 7 & + & 5 & $\begin{array}{c}1,518 \\
(763-2,400)\end{array}$ & $\begin{array}{c}452 \\
(357-549)\end{array}$ & $\begin{array}{c}2.20 \\
(1.75-2.79)\end{array}$ & $\begin{array}{c}1,342 \\
(1,134-1,500)\end{array}$ & $\begin{array}{c}29.5 \\
(19.9-40.6)\end{array}$ \\
\hline
\end{tabular}

* Antikidney serum injections given to Series A rats after 14 days of high lipid diet. $\dagger$ Range of values. 
TABLE IV

Effect of nephrosis on rate of hepatic elimination of excess cholesterol

\begin{tabular}{|c|c|c|c|c|c|c|}
\hline \multirow[b]{3}{*}{ Group } & \multirow[b]{3}{*}{$\begin{array}{l}\text { No. of } \\
\text { rats }\end{array}$} & \multirow[b]{3}{*}{ No. of hours } & \multicolumn{4}{|c|}{ Average concentration } \\
\hline & & & \multicolumn{3}{|c|}{ Plasma } & \multirow{2}{*}{$\frac{\text { Liver }}{\begin{array}{c}\text { Total } \\
\text { cholesterol }\end{array}}$} \\
\hline & & & $\begin{array}{c}\text { Total } \\
\text { cholesterol }\end{array}$ & $\begin{array}{l}\text { Phospho- } \\
\text { lipids }\end{array}$ & $\begin{array}{l}\text { Total } \\
\text { lipids }\end{array}$ & \\
\hline \multicolumn{4}{|c|}{$\begin{array}{r}m . / 100 \mathrm{ml} . \\
\text { A. Rats injected with hypercholesteremic serum and antikidney serum }\end{array}$} & $m g . / 100 \mathrm{ml}$ & $m g . / 100 \mathrm{ml}$. & $m g . / 100 \mathrm{Gm}$. \\
\hline 1 & 6 & Immed. postinjection & $\begin{array}{l}240 \\
(226-277)^{*}\end{array}$ & & & \\
\hline 2 & 6 & 6 hours & $\begin{array}{c}156 \\
(139-170)\end{array}$ & & & $(1,300-1,370)$ \\
\hline 3 & 6 & 24 hours & $\begin{array}{c}95 \\
(72-129)\end{array}$ & $\begin{array}{c}154 \\
(135-191)\end{array}$ & $\begin{array}{c}348 \\
(317-396)\end{array}$ & $\begin{array}{c}883 \\
(739-985)\end{array}$ \\
\hline 4 & $5 \dagger$ & 48 hours & $\begin{array}{c}117 \\
(101-124)\end{array}$ & & & $\begin{array}{c}858 \\
(767-920)\end{array}$ \\
\hline \multicolumn{7}{|c|}{ B. Control rats injected with hypercholesteremic serum } \\
\hline 5 & 20 & Preinjection & $\begin{array}{c}55 \\
(42-68)\end{array}$ & $(83-128)$ & $\begin{array}{c}187 \\
(140-225)\end{array}$ & $\begin{array}{r}893 \pm 29.1 \ddagger \\
(714-1,080)\end{array}$ \\
\hline 6 & 8 & Immed. postinjection & $\begin{array}{c}255 \\
(216-273)\end{array}$ & $\begin{array}{c}518 \\
(414-708)\end{array}$ & $\begin{array}{c}787 \\
(678-955)\end{array}$ & \\
\hline 7 & 10 & 2 hours & $\begin{array}{c}212 \\
(191-230)\end{array}$ & $\begin{array}{c}401 \\
(372-440)\end{array}$ & $\begin{array}{c}615 \\
(570-640)\end{array}$ & $\begin{array}{c}1,420 \\
(1,237-1,670)\end{array}$ \\
\hline 8 & 6 & 6 hours & $\begin{array}{c}154 \\
(129-180)\end{array}$ & & & $\begin{array}{c}1,285 \\
(1,160-1,400)\end{array}$ \\
\hline 9 & 10 & 24 hours & $\begin{array}{c}61 \\
(47-80)\end{array}$ & $\begin{array}{c}138 \\
(95-150)\end{array}$ & $\begin{array}{c}201 \\
(144-230)\end{array}$ & $\begin{array}{c}871 \\
(678-1,065)\end{array}$ \\
\hline 10 & 13 & 48 hours & $\begin{array}{c}73 \\
(47-87)\end{array}$ & & & $\begin{array}{c}855 \\
(714-1,050)\end{array}$ \\
\hline
\end{tabular}

* Range of values.

$\dagger$ These rats injected with antikidney serum 24 hours after injection of hypercholesteremic serum.

$\ddagger$ S.E. of mean.

fed stock ration. Plasma cholesterol was determined in all rats at the end of the bile collection period and the bile analyzed for its cholate concentration.

\section{Results}

As shown in Table III, moderate hypercholesteremia and hyperlipemia and a marked rise of liver cholesterol occurred during the 14 day preliminary period of high lipid feeding (Group 1). Three days after changing to stock ration, plasma lipid concentrations returned to normal in the control rats, and their hepatic cholesterol content diminished somewhat (Group 2b). A further decrease of liver cholesterol occurred by the seventh day (Group 3b); and 11 days (Group 4b) after stopping the diet supplement, the liver cholesterol concentrations had decreased from the initial average level of $17,171 \mathrm{mg}$. per $100 \mathrm{Gm}$. to an average of $4,615 \mathrm{mg}$. per $100 \mathrm{Gm}$. The injection of AKS into such pre-fed rats induced a severe hyperlipemia and hypercholesteremia (Group 2a) which increased until the seventh day (Group 3a) after AKS injection and then diminished (Group 4a). Despite occurrence of such severe hypercholesteremia, a progressive elimination of the excess liver cholesterol also occurred in these pre-fed, AKS-injected rats which paralleled that in their respective controls, falling to an average of $3,682 \mathrm{mg}$. per $100 \mathrm{Gm}$. by 11 days (Group 4a) after transferring to stock diet.

In similar fashion, the development of AKSinduced hypercholesteremia again was not found to interfere with the hepatic elimination of the excess cholesterol contained in the injected hypercholesteremic rat serum. Such serum is essentially free of triglycerides and, as shown in Table IV, its injection also did not induce any rise of plasma triglycerides in the control rats (Groups 6 and 7). Rapid plasma clearance and 
hepatic uptake of the injected cholesterol occurred in the control rats (Groups 6 to 10), with complete elimination by the liver of the excess cholesterol within 24 hours after its injection (Group 10). The concomitant injection of AKS was not found to interfere either with rapid plasma clearance and hepatic uptake of the injected cholesterol (compare Groups 2 and 8 ), or with the subsequent progressive hepatic elimination of the excess deposited cholesterol (compare Groups 3 and 9), despite the occurrence of AKS-induced rise of plasma cholesterol. That the hypercholesteremia present 24 hours after AKS injection (Group 3) was actually induced by the AKS, rather than being due to any AKS-induced delay in plasma clearance of the injected load of cholesterol, is apparent first from the larger ratio of cholesterol to phospholipid in these rats than occurs in rats injected with the hypercholesteremic rat serum (see Groups 6 and 7), and second, from the concomitantly elevated plasma triglyceride concentration which, by calculation of difference between total lipid and the sum of total cholesterol plus phospholipid, averaged $99 \mathrm{mg}$. per $100 \mathrm{ml}$. in Group 3 while the corresponding value for Groups 6 and 7 is virtually zero.

Hepatic elimination of cholesterol is normally accomplished primarily by its conversion to cholic acid, which is subsequently excreted via the bile (5). As previously observed (5), therefore, the bile cholate concentration was found to be somewhat increased in the control rats whose hepatic cholesterol content was increased by the prior injection of hypercholesteremic rat serum (see Table V; compare Groups 4 and 5), and markedly increased in the control rats pre-fed excess dietary cholesterol (Group 2). In each instance a comparably increased bile cholate concentration was observed in the similarly treated rats which also had been injected with AKS (Groups 3 and 1, respectively), despite the occurrence of AKSinduced hypercholesteremia in these groups of rats.

C. Possible role of hepatic reticuloendothelial cells (R.E.) in nephrotic hyperlipemia and hypercholesteremia. In view of previous studies $(15,16)$ of the role of hepatic R.E. cell participation in the plasma egress of exogenously derived cholesterol, it also was believed important to study the possible causal role of this cell system in the genesis of nephrotic hyperlipemia and hypercholesteremia.

Methods: 1. Effect of nephrosis on R.E. cell function. Hepatic R.E. cell function was studied in seven nephrotic rats which had been injected with AKS either 24 hours (four rats) or seven days (three rats) previously. An

TABLE V

Effect of nephrosis on hepatic conversion of cholesterol to cholate

\begin{tabular}{|c|c|c|c|c|c|c|}
\hline \multirow[b]{4}{*}{ Group } & \multirow{4}{*}{$\underset{\text { injection }}{\text { AKS }}$} & \multirow{4}{*}{$\begin{array}{l}\text { No. of } \\
\text { rats }\end{array}$} & \multicolumn{4}{|c|}{ Average concentration } \\
\hline & & & \multirow{3}{*}{$\frac{\text { Plasma }}{\begin{array}{c}\text { Total } \\
\text { cholesterol }\end{array}}$} & \multicolumn{3}{|c|}{ Bile } \\
\hline & & & & \multirow[b]{2}{*}{ Volume } & \multicolumn{2}{|c|}{ Cholate } \\
\hline & & & & & Concentration & Content \\
\hline & & & mg./100 ml. & $m l$. & $m g . / 100 \mathrm{ml}$. & $m g . / 24 \mathrm{hrs}$. \\
\hline \multicolumn{7}{|c|}{ A. Rats pre-fed fat and cholesterol for 10 days } \\
\hline 1 & + & 3 & $\begin{array}{c}623 \\
(504-743) \dagger\end{array}$ & $\begin{array}{c}11.7 \\
(9.5-14.5)\end{array}$ & $\begin{array}{c}563 \pm 136.4^{*} \\
(342-890)\end{array}$ & $\begin{array}{c}65.8 \\
(50.0-85.0)\end{array}$ \\
\hline 2 & - & 5 & $\begin{array}{c}244 \\
(116-407)\end{array}$ & $\begin{array}{c}17.3 \\
(13.4-22.0)\end{array}$ & $\begin{array}{r}392 \pm 42.0 \\
(256-545)\end{array}$ & $\begin{array}{c}67.8 \\
(52.3-103.5)\end{array}$ \\
\hline \multicolumn{7}{|c|}{ B. Rats injected with hypercholesteremic rat serum $\ddagger$} \\
\hline 3 & + & 4 & $\begin{array}{c}137 \\
(112-155)\end{array}$ & & $\begin{array}{r}284 \pm 16.2 \\
(235-323)\end{array}$ & \\
\hline 4 & - & 8 & $\begin{array}{c}100 \\
(86-111)\end{array}$ & & $\begin{array}{c}221 \pm 6.8 \\
(191-247)\end{array}$ & \\
\hline \multicolumn{7}{|c|}{ C. Control rats fed stock ration } \\
\hline 5 & - & 8 & $\begin{array}{c}54 \\
(42-69)\end{array}$ & $\begin{array}{c}14.8 \\
(11.8-17.5)\end{array}$ & $\begin{array}{c}197 \pm 8.7 \\
\quad(152-225)\end{array}$ & $\begin{array}{c}29.2 \\
(22.1-36.2)\end{array}$ \\
\hline
\end{tabular}

* S.E. of mean.

$\uparrow$ Range of values

$\mp$ Bile collected only 12 hours in these rats. 
TABLE VI

Effect of India ink injections on plasma lipids of rats concomitantly injected with antikidney serum (AKS)

\begin{tabular}{|c|c|c|c|c|c|}
\hline \multirow[b]{2}{*}{ Type of rat } & \multirow[b]{2}{*}{$\begin{array}{l}\text { No. of } \\
\text { rats }\end{array}$} & \multirow[b]{2}{*}{$\begin{array}{c}\text { Average } \\
\text { weight }\end{array}$} & \multicolumn{3}{|c|}{ Average plasma concentrations (mg./100 ml.) } \\
\hline & & & $\begin{array}{l}\text { Total } \\
\text { lipids }\end{array}$ & $\begin{array}{c}\text { Total } \\
\text { cholesterol }\end{array}$ & Phospholipids \\
\hline Treated* & 6 & $\begin{array}{l}G m . \\
200\end{array}$ & $\begin{array}{c}644 \\
(446-816) \dagger\end{array}$ & $\begin{array}{c}198 \\
(132-264)\end{array}$ & $\begin{array}{c}272 \\
(205-305)\end{array}$ \\
\hline Untreated $\ddagger$ & 6 & 206 & $\begin{array}{c}680 \\
(404-1,070)\end{array}$ & $\begin{array}{c}189 \\
(119-237)\end{array}$ & $\begin{array}{c}286 \\
(187-373)\end{array}$ \\
\hline
\end{tabular}

* AKS plus India ink.

$\dagger$ Range of values.

$\ddagger$ AKS only.

additional five rats served as controls. During abdominal laparotomy under light ether anesthesia, each rat was rapidly injected via the inferior vena cava with $1.0 \mathrm{ml}$. of solution containing $10 \mu \mathrm{c}$. of $\mathrm{CrP}^{32} \mathrm{O}_{4}$ (17) (particle size : 0.2 to $2.0 \mu$ ). Four identical samples of $0.034 \mathrm{ml}$. of blood were then serially pipetted from the previously cut' tail at 60 second intervals, each aliquot being spread on a small copper plate, dried, and its activity counted using an end-window Geiger-Müller tube.

Six of a second series of 10 rats also were injected with AKS, and 72 hours later the six nephrotics and four controls were injected with $\mathrm{CrP}^{32} \mathrm{O}_{4}$, as above. Blood sampling was done one and five minutes later, and immediately thereafter the hepatic blood supply was clamped, the liver removed, and a thin slice of $40 \mathrm{mg}$. of liver then washed in saline, dried, and its activity counted. Plasma cholesterol was determined in all rats at the time of sacrifice.

2. Effect of R.E. cell "blockade" on AKS-induced hyperlipemia and hypercholesteremia. The effect of R.E. cell "blockade" on nephrotic rats was then studied. A series of 12 rats was injected with AKS. Six of the rats were also injected intravenously with $1.0 \mathrm{ml}$. of 20 per cent India ink suspensions twice daily for two days prior to and for two days following AKS injection. All rats then were bled for plasma total lipids, phospholipids and total cholesterol.

\section{Results}

Figure 2 shows the rate of plasma clearance of the injected $\mathrm{CrP}^{32} \mathrm{O}_{4}$ in the nephrotic and the control rats and indicates that as rapid a plasma egress of radioactivity occurred in both the acute and the chronic nephrotic rats as occurred in the control rats. Plasma total cholesterol averaged $135 \mathrm{mg}$. per $100 \mathrm{ml}$. (range, 118 to 167 ) in the acute nephrotic rats, $523 \mathrm{mg}$. per $100 \mathrm{ml}$. (range, 316 to 664 ) in the more chronic nephrotic animals, and $58 \mathrm{mg}$. per $100 \mathrm{ml}$. (range, 48 to 70 ) in the control group.

Similar rates of plasma clearance of radioac- tivity again were noted in the second series of rats, the hepatic uptake of radioactivity averaging 234 cpm per mg. of liver (range, 178 to 311 ) in the nephrotic rats, and $211 \mathrm{cpm}$ per $\mathrm{mg}$. of liver (range, 125 to 260) in the control group.

The repeated injections of the colloidal suspension of India ink did not appear to influence the magnitude of AKS-induced hyperlipemia. Thus, as shown in Table VI, plasma total lipids, cholesterol and phospholipid concentrations were closely comparable in the treated and untreated groups of nephrotic rats.

\section{DISCUSSION}

The present results indicate that the rise of plasma cholesterol occurring in AKS-injected rats could not be ascribed to any failure of the liver's ability to eliminate cholesterol by its normal disposal route, the conversion to cholate, which is subsequently excreted in the bile (5). Thus, neither the injection of AKS nor the occurrence

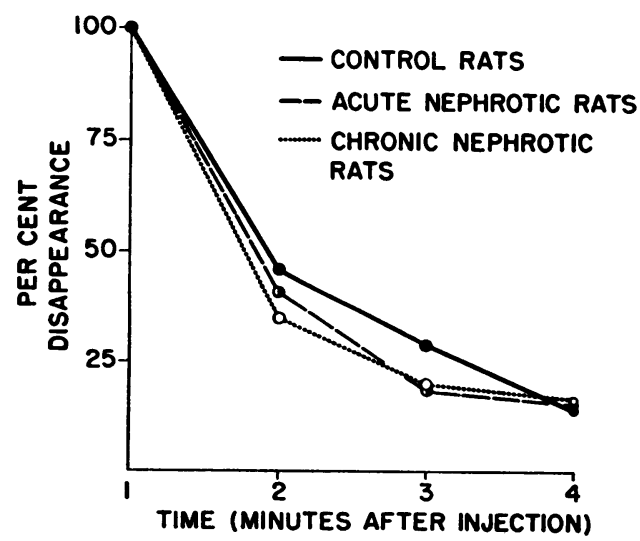

Fig. 2. Rate of Disappearance of $\mathrm{C}_{\mathrm{R}} \mathrm{P}^{22} \mathrm{O}_{4}$ From Plasma of Nephrotic Rats 
of nephrotic hypercholesteremia and hyperlipemia was found to prevent the normal hepatic conversion of cholesterol to cholate and consequent normal rate of hepatic elimination of excess intrahepatic cholesterol. This was found true whether the excess hepatic cholesterol content was derived from an exogenous source, the diet or an endogenous source, hypercholesteremic rat serum obtained from biliary-obstructed rats (12).

The data also indicate that the AKS-induced hypercholesteremia could not be ascribed to any prior or pari passu accumulation of cholesterol in the liver. The injection of potent AKS leads to a progressive rise of plasma triglycerides and cholesterol for some 72 to 96 hours after its administration (18). During this phase, the excess cholesterol in the plasma is largely present in a nondiffusible form (19). As a probable consequence, little or no early rise of liver cholesterol occurred in the AKS-injected rats, despite their persistent hypercholesteremia, and in contrast to the rapid plasma clearance and rise of liver cholesterol which occurred in rats injected with a load of a diffusible form of excess cholesterol $(13,20)$. Although a similar mechanism has not been demonstrated in the human disease, a comparable alteration of plasma-liver exchange of cholesterol has been noted in other experimental hypertriglyceridemic states in which associated excess plasma cholesterol is also transported in a nondiffusible form, namely in rats during the first 36 hours after injection of Triton ${ }^{\circledR}$ WR-1339 (13), and in rats continuously infused with triglycerides (21). The present findings are thus consistent with earlier demonstrations $(19,22,23)$ of an intravascular partial block to the egress of cholesterol from nephrotic plasma, apparently occurring as a passive consequence of the excess triglycerides present in such plasma $(18,21,24)$.

Finally the present results indicate that nephrotic hypercholesteremia and hyperlipemia cannot be ascribed to any abnormality of hepatic Kupffer cell function possibly induced by AKS. Earlier studies from this laboratory showed that the hepatic R. E. cell plays an important role in the disposition of dietary-derived (15) but not endogenously-derived (16) cholesterol in the rat. A possible role of altered Kupffer cell function in the genesis of nephrotic hypercholesteremia was considered because, although of endogenous origin
(23), the lipid spectrum of nephrotic plasma resembles an exaggerated alimentary hyperlipemia, characterized as it is by a relatively greater excess of triglycerides (18) and chylomicronemia (24). However, no abnormality of Kupffer cell function, as presently assayed, was found in the nephrotic rats. Moreover, the hypercholesteremia induced by AKS injection was not augmented by the interference with Kupffer cell function (15) consequent to repeated injection of colloidal suspensions of India ink.

\section{SUMMARY}

The possible role of any alteration of hepatic parenchymal and Kupffer cell function in the genesis of nephrotic hypercholesteremia was investigated in rats with nephrosis induced by injection of antirat kidney serum. The hypercholesteremia was not found to be ascribable to any accumulation of liver cholesterol, to any failure of hepatic conversion of cholesterol to cholate, or to any abnormality of Kupffer cell function.

\section{REFERENCES}

1. Heymann, W., and Lund, H. Z. Nephrotic syndrome in rats. Pediatrics 1951, 7, 691.

2. Byers, S. O., Friedman, M., and Rosenman, R. H. Hepatic synthesis of cholesterol in nephrotic rats. Amer. J. Physiol. 1954, 178, 327.

3. Rosenman, R. H., Friedman, M., and Byers, S. O. Intestinal absorption of cholesterol by the nephrotic rat. Circulat. Res. 1954, 2, 256.

4. Byers, S. O., Rosenman, R. H., and Friedman, M. Intestinal excretion of cholesterol and total lipids by the nephrotic rat. Amer. J. Physiol. 1955, 182, 73.

5. Friedman, M., Byers, S. O., and Gunning, B. Observations concerning production and excretion of cholesterol in mammals. VIII. Fate of injected cholesterol in the animal body. Amer. J. Physiol. 1953, 172, 309.

6. Friedman, M., Byers, S. O., and Shibata, E. Observations concerning the production and excretion of cholesterol in mammals. X. Factors affecting the absorption and fate of ingested cholesterol. $\mathrm{J}$. exp. Med. 1953, 98, 107.

7. Saifer, A., and Kammerer, O. F. Photometric determination of total cholesterol in plasma or serum by a modified Liebermann-Burchard reaction. J. biol. Chem. 1946, 164, 657.

8. Zilversmit, D. B., and Davis, A. K. Microdetermination of plasma phospholipids by trichloroacetic acid precipitation. J. Lab. clin. Med. 1950, 35, 155. 
9. Bragdon, J. H. Colorimetric determination of blood lipides. J. biol. Chem. 1951, 190, 513.

10. Friedman, M., Byers, S. O., and Rosenman, R. H. Changes in excretion of intestinal cholesterol and sterol digitonides in hyper- and hypothyroidism. Circulation 1952, 5, 657.

11. Friedman, M., Byers, S. O., and Michaelis, F. Bile acid content of rat bile and of normal and icteric rat plasma. Amer. J. Physiol. 1951, 164, 786.

12. Byers, S. O., and Friedman, M. Extreme hypercholesteremia following administration of cholic acid to the bile duct ligated rat. Fed. Proc. 1951, 10, 22.

13. Friedman, M., and Byers, S. O. Mechanism underlying hypercholesteremia induced by Triton WR1339. Amer. J. Physiol. 1957, 190, 439.

14. Friedman, M., Byers, S. O., and Michaelis, F. Observations concerning production and excretion of cholesterol in mammals. II. Excretion of bile in the rat. Amer. J. Physiol. 1950, 162, 575.

15. Friedman, M., Byers, S. O., and Rosenman, R. H. Observations concerning the production and excretion of cholesterol in mammals. XII. Demonstration of the essential role of the hepatic reticuloendothelial cell (Kupffer cell) in the normal disposition of exogenously derived cholesterol. Amer. J. Physiol. 1954, 177, 77.

16. Friedman, M., and Byers, S. O. Observations concerning the production and excretion of cholesterol in mammals. XIV. The relationship of the hepatic reticulo-endothelial cell (Kupffer cell) to endogenously produced cholesterol. Circulation 1954, 10, 491.

17. Jallut, O., Peguidon, L., Lerch, P., Neukomm, S., and Feissly, R. Speed of disappearance from the blood and distribution in different organs of radioactive colloidal $\mathrm{CrPO}_{4}$ as a function of the injected particle size. Bulletin of the Society for Research on the Reticuloendothelial System 1955, 1, 70.

18. Rosenman, R. H., Byers, S. O., and Friedman, M. Plasma lipid interrelationships in experimental nephrosis. J. clin. Invest. 1957, 36, 1558.

19. Friedman, M., Rosenman, R. H., and Byers, S. O. The lipid and cholesterol content of hepatic lymph in experimental nephrosis. Amer. J. Physiol. 1957, $190,180$.

20. Friedman, M., Byers, S. O., and Omoto, C. Some characteristics of hepatic lymph in the intact rat. Amer. J. Physiol. 1956, 184, 11.

21. Friedman, M., and Byers, S. O. Role of hyperlipemia in the genesis of hypercholesteremia. Proc. Soc. exp. Biol. (N. Y.) 1955, 90, 496.

22. Rosenman, R. H., Friedman, M., and Byers, S. O. The distribution of cholesterol and total lipids in the nephrotic rat. J. clin. Invest. 1955, 34, 700.

23. Friedman, M., Rosenman, R. H., and Byers, S. O. The role of exogenous lipids in the hyperlipemia and hypercholesteremia of nephrotic rats. J. clin. Invest. 1954, 33, 1103.

24. Byers, S. O., and Friedman, M. The fractionation of cholesterol in body fluids by means of solvent extraction. J. clin. Invest. 1956, 35, 405. 